\title{
Editorial
}

\section{The Growing Importance of State Library Associations}

Change is occurring faster than ever before in the history of libraries. This unprecedented rapidity in change is especially noticeable in academic libraries. Moreover, change is now more discontinuous, more ambiguous, and certainly involves greater risk. There is greater competition in the delivery of library services. One of the primary driving forces of change in academic libraries is technology. Among its many positive attributes, technology has enabled the library to become a much more integral part of the academic enterprise. Moreover, we should expect even greater things from the evolving technology.

\section{More Continuing Education, More Training}

To keep current with the various changes occurring in libraries, library staff has to be given the opportunity to engage in continuing education activities and training sessions. Without this opportunity, it will, in time, fall farther behind in its effectiveness in organizing, delivering, and accessing those components and services expected by students and faculty. We are being swept downstream by a torrent of change while, concurrently, fewer funds are available to assist library staff in retooling and training. The days when change in academic libraries resembled a slow-running river are long gone.

Unfortunately, many library staff members cannot attend the various national and regional library conferences and meetings due to a lack of travel funds. An examination of the composition of the various ALA committees reveals that there are far more administrators than nonadministrative librarians.

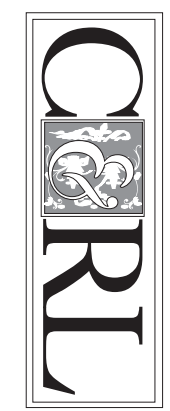
And there is next to no support staff on these important committees or in attendance at the ALA midwinter meetings and annual conferences. This is a sad commentary on a profession that depends heavily on nonprofessional staff to get the bulk of the work done in academic libraries. The lack of opportunity for support staff to participate in regional and national library and information science conferences is now being compounded by a blurring of work responsibilities and duties between librarians and support staff. More of the daily application of technology in academic libraries can be-and is being-accommodated by support staff. These staff members require regular updating of their skills-and this updating of skills extends far beyond technology.

\section{Role of State Library Associations}

All fifty states have a state library association. Most of these associations focus on advancing and promoting libraries and librarianship in their respective states. In addition, most of them have a

\section{The days when change in academic libraries resembled a slow-running river are long gone.}

college and university section/division, along with sections/divisions for other types of libraries. Annual conferences, section meetings, strategic plans, and ongoing continuing education opportunities are common elements of state library associations. 
Moreover, state library associations normally have a hand-in-glove working relationship with their state libraries. A positive, constructive working relationship between these two organizations can pay many dividends, especially when attempting to get additional funding from the state legislature.

The ACRL currently has forty-two state chapters that work closely with state library associations' college and university sections. The ACRL chapters play an important role in introducing best practices in various areas and providing topical discussions on evolving developments in academic libraries. ACRL members who cannot attend the national conferences have an opportunity to participate in ACRL programs within their own states. Some ACRL chapters are regional and are capable of offering expanded programs.

\section{Additional Responsibilities}

Based on my experience as president of three state library associations (Arizona, Colorado, and West Virginia) and attending several conferences of other state library associations, I have been quite impressed with the enthusiasm, energy, and work shown by their members. Some state library associations (e.g., the Texas Library Association) are well known for holding effective and impressive annual conferences. I served as a speaker at the Texas Library Association 1989 and 1998 annual conferences. Even though I was extremely pleased with what I observed at the 1989 conference, the 1998 conference was "megaimpressive." Its programs focused on the key issues facing the profession today and offered more than one would expect from a state library association. In addition, there were more exhibitors than one would anticipate. Why are the TLA conferences well attended? Over the years, the TLA has taken its members' needs seriously and has designed its programs to exceed their expectations. Other state library associations do very well and can serve as a model for those that are struggling. Library associations in states with large populations are expected to have an advantage over those in less populated states. However, size should not be perceived as a handicap when program planning is at stake. Indeed, I have witnessed many excellent programs sponsored by library associations in small

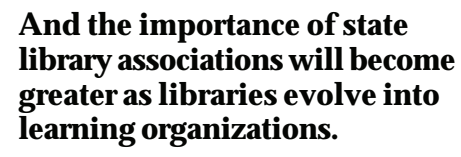

states.

The magnitude of the ever-changing environment in academic libraries will expand dramatically as we move into the twenty-first century. It is anticipated that nearly all of an academic library's staff will experience more training, retraining, and, in a sense, regular renewing. And the importance of state library associations will become greater as libraries evolve into learning organizations. Peter M. Senge believes that the organization that will truly excel in the future will be the one that discovers how to tap people's commitment and capacity to learn at all of its levels. ${ }^{1}$ Along with the professionals, the support staff in academic libraries must be engaged in an ongoing learning process. Support staff should not be perceived as second-class citizens in any library; they can no longer be ignored and their skills must be upgraded on a regular basis. The importance of state library associations in advancing libraries and librarianship is magnifying each year. They are to be applauded for their fine work! And they should be expected to deliver more in the future. I think they will.

DONALD E. RIGGS

\section{Note}

1. Peter M. Senge, The Fifth Discipline: The Art and Practice of the Learning Organization (New York: Doubleday Currency, 1990), 14. 